\title{
In-depth analysis of potential tissue donors in Korea
}

\author{
Haejin Park, Jaeuk Woo, Yongmin Lee, Myounghwa Lee, Ohhyuk Yun, Jeongrim Lee, Insung Moon
}

Korea Organ Donation Agency, Seoul, Korea

Background: In Korea, there are fewer cases of tissue donations compared to organ donations from brain-death (BD). Thus, this paper hopes to explore means to increase and stimulate tissue donation based on an analysis of donors who consented to become potential human tissue donors between 2018 and 2020, but discontinued.

Methods: Among a group of 538 people who consented to donate their tissue from January 1, 2018, to December 31, 2020, this paper analyzed 208 people who discontinued and 38 people whose tissue was collected but subsequently disposed of.

Results: Over a 3-year period, 7,393 patients were registered as potential donors at the Korea Organ Donation Agency. Five hundred thirty-eight patients $(27 \%$ ) of the 7,393 agreed to donate tissue-consent rate was $11.9 \%$ (BD 9.7\%; circulatory death [CD] $2.2 \%$ ). Among them, 330 patients $(61 \%, 250$ men, 80 women) donated tissue, 208 patients stopped tissue donation and the tissue collected from 38 patients $(12 \%)$ were discarded tissue processing. Most of the reasons for stopping tissue donation were the possibility of infection (139 patients; BD 111, CD 28) and herpes simplex (24 patients; BD 22, CD 2). Most of the reasons for disposal are identification of bacteria in blood and tissues (27 patient; BD 11, CD 16).

Conclusions: Along with in-depth research in order to reduce the discontinuation of tissue donations and the rate of discarded tissue upon collection, we must provide precise standards for assessing potential infection and also focus on installing an aseptic culture system. Moreover, we must develop a guideline for evaluating the suitability of tissue donation in Korea with accurate physical assessments and verification of medical records.

Corresponding author: Jaeuk Woo

E-mail: ju.woo@koda1458.kr

(C) The Korean Society for Transplantation

This is an Open Access article distributed under the terms of the Creative Commons Attribution Non-Commercial License (http://creativecommons.org/licenses/by-nc/4.0/) which permits unrestricted non-commercial use, distribution, and reproduction in any medium, provided the original work is properly cited. 